\title{
Recommendations for sedation outside the operating room during the COVID-19 pandemic
}

\section{Recomendaciones para sedación fuera de quirófa no en la pandemia de la COVID-19}

\author{
Liliana Suárez Aguilar ${ }^{a}$ (D) \\ a Scientific director, HYPNOS Sedaciones. Bogotá, Colombia. \\ Correspondence: HYPNOS Sedaciones, avenida carrera 15 \# 124-47, consultorio 702. Bogotá, Colombia. E-mail: lilisuareza@gmail.com
}

\section{What do we know about this problem?}

- The current COVID-19 pandemic has caused a huge concern among the scientific societies worldwide.

- Current protocols have not included the diagnostic and/or therapeutic procedures performed outside the operating room under sedation.

- The large healthcare organizations and the national government agencies have made available valuable information about biosecurity protocols and the correct use of personal protective equipment (PPE).

\section{What is the contribution of this study?}

Provide guidance to the healthcare teams participating in diagnostic and/or therapeutic procedures under sedation, outside the operating room, during COVID-19 times.

\section{¿Qué sabemos acerca de este problema?}

- La pandemia actual de la COVID-19 ha causado dentro de las sociedades científicas del mundo.

- Los protocolos actuales no han incluido los procedimientos diagnósticos y/o terapéuticos que se realizan fuera de quirófano, bajo sedación. - Las grandes organizaciones de salud y las entidades gubernamentales nacionales han proporcionado información valiosa sobre los protocolos de bioseguridad y uso correcto de los elementos de protección personal (EPP).

\section{¿Qué aporta de nuevo este estudio?}

- Dar orientación a los equipos de salud que ofrecen sus servicios en procedimientos diagnósticos y/o terapéuticos bajo sedación fuera de quirófano en época de pandemia por la COVID-19.

\section{How to cite this article}

Suárez Aguilar L. Recommendations for sedation outside the operating room during the COVID-19 pandemic. Colombian Journal of Anesthesiology. 2020;48(4):e929.

\section{Abstract}

The current spread of SARS-CoV-2 (Severe Acute Respiratory Syndrome Coronavirus 2) and its disease COVID-19, has confronted society with a paradigm shift in all fields: political, social, religious, economic, and healthcare is no exception. This has created challenges for the adequate and safe delivery of services for patients and healthcare workers.

Notwithstanding the global efforts to contain the spread of the disease, the outbreak continues to escalate. COVID-19 is currently the disease receiving the most attention worldwide; however, patients continue to present other conditions that demand the same level of care to be effectively controlled, so that they do not become another healthcare concern, as a result of potential secondary complications due to poor care.

This reflection article gives recommendations to care for patients requiring diagnostic and/or therapeutic procedures under sedation, outside the operating room, keeping the current standards and biosecurity protocols in mind. Moreover, it provides a brief description of the disease, symptoms, diagnosis and transmission routes.

\section{Keywords}

Sedation; procedures outside the operating room; pandemic; COVID-19; personal protection elements.

\section{Resumen}

La actual propagación del SARS-CoV-2 (Coronavirus 2 del síndrome respiratorio agudo severo) y su enfermedad, la COVID-19, ha enfrentado a la sociedad a un cambio de paradigmas en todos los aspectos: político, social, religioso, económico, y el área de la salud no es la excepción; lo que ha generado retos para la adecuada prestación de servicios dentro del marco de seguridad para los pacientes y el personal asistencial.

A pesar de los esfuerzos mundiales para contener la propagación de la enfermedad, el brote sigue en aumento. La COVID-19 es en este momento la enfermedad de mayor atención en el mundo, pero los pacientes siguen presentando otras patologías que requieren igual atención para ser controladas de manera eficaz, de modo que no se conviertan en otro problema para los sistemas de salud por las posibles complicaciones secundarias a la desatención de las mismas.

Este artículo de reflexión brinda recomendaciones para la atención de pacientes que requieren procedimientos diagnósticos y/o terapéuticos bajo sedación fuera de quirófanos, teniendo en cuenta la normatividad actual y los protocolos de bioseguridad vigentes; adicionalmente, proporciona una breve descripción de la enfermedad, síntomas, diagnóstico y rutas de transmisión.

\section{Palabras clave}

Sedación; procedimientos fuera del quirófano; pandemia; COVID-19; elementos de protección personal. 


\section{INTRODUCTION}

The worldwide emergency was declared by the World Health Organization (WHO) on March 11, 2020, due to the fast dissemination of a new coronavirus (SARSCoV-2) considered potentially lethal. (1) The virus originated in Wuhan, Capital of Hubei Province in China, in 2019 (2), with a rapid spread that caused a high mortality. As of that moment, the world has experienced a major paradigm shift in terms of what the value of life means; governments around the world have adopted measures with the only purpose of fighting against a new enemy from all fields: political, economic, social, environmental, and of course from the health perspective. However, this doesn't mean that the diseases and the needs of patients have ceased. One of those needs is the possibility for anesthesiologists to conduct diagnostic and/or therapeutic procedures under sedation, outside the operating room, safely and objectively, based on the priority of the intervention to avoid additional exposure both of patients and healthcare providers. It is then timely to make recommendations about the most relevant aspects of COVID-19, the selection of patients and procedures, ensuring biosecurity for the patient, the specialist doing the procedure, the anesthesiologist, and the attending healthcare staff.

In order to make this review more valuable, a search was conducted in PubMed using the following terms: ("COVID-19" OR "coronavirus" OR "SARS-Cov-2") AND ("sedation") AND ("Office-based anesthesia"). No results were found when combining COVID-19 with sedation outside the operating room and hence recommendations and reports from various specialties such as gastroenterology and dentistry, as well the $\mathrm{WHO}$, were considered to prepare this article. There were no restrictions regarding dates, language, or any other type. A total of 11,202 results were found until May 12, 2020 with the initial keywords, of which the most relevant were selected. References from primary articles considered to be important were also consulted for this paper.

\section{BACKGROUND}

Wuhan city in China became the focus of worldwide attention due to the outbreak of a febrile, respiratory disease caused by a 2019-nCoV coronavirus or SARS-CoV-2. In December 2019, an outbreak of pneumonia of unknown cause was identified, with an epidemiological link to the Huanan Seafood Wholesale market where live animals were sold and the virus is considered to have a zoonotic origin; in other words, the virus was transmitted from an animal host to a human. $(3,4)$

Coronaviruses are a group of positive sense single-stranded RNA viruses of the Coronaviridae family that infect both animals and humans. Human coronaviruses may cause a mild disease similar to a common cold, whilst other viruses cause more severe conditions (such as MERS [Middle East Respiratory Syndrome] and SARS [Severe Acute Respiratory Syndrome]) (5). There are currently four coronavirus subgroups: $a-C o V, \beta-C o V, y-C o V$ and $\delta-C o V$. Most coronaviruses may cause infections in humans and vertebrates; the $\mathrm{a}-\mathrm{CoV}$ and $\beta-\mathrm{CoV}$ mainly infect the respiratory tract, the $\mathrm{Cl}$ tract and the central nervous system of humans and mammals, whilst the $y$-CoV and $\delta$-CoV primarily infect birds. According to the phylogenetic analysis based on the virus genome, the 2019-nCoV or SARSCoV-2 identified in Wuhan is also a member of the $\beta$-CoV. $(6,7)$

Understanding the mode of transmission of the virus is one of the cornerstones for the development of biosecurity protocols in all areas, keeping in mind that until this date, there is no proven effective treatment or vaccine developed that ensures the cure or elimination of the disease. Hence, the essential tool for prevention is the adequate use of personal protective equipment (PPE) and self-care measures that must be promoted in the community in general, since all age groups, genders and races are susceptible of acquiring and developing the disease. The virus spreads through microdroplets of saliva, aerosols, and close contact (anyone who has been less than 2 $\mathrm{mt}$ apart from a confirmed case, while the subject was symptomatic, or during the 48 hours prior to the onset of symptoms for at least 15 minutes)(8) with the infected person, whether with or without symptoms. The droplets are heavy and usually spread around a maximum radius of 2 meters after coughing, sneezing, and depositing on surfaces. The livability of the virus varies; for instance, the half-life of SARS-CoV- 2 in aerosols on copper, cardboard, stainless steel and plastic is of $4,24,5.6$ and 6.8 hours, respectively. It has been found that the virus may survive after being released in aerosols for up to 3 hours in the room. Furthermore, the virus has been found in the blood and feces of infected patients, and this becomes yet another route of potential contagion; these aerosols may enter through different pathways into the body, for instance via the conjunctiva, or through fluid contamination. (9-14)

\section{CLINICAL CONSIDERATIONS}

The clinical characteristics of COVID-19 are varied, ranging from the asymptomatic status to the acute respiratory distress syndrome and multiple organ failure. Some of the usual clinical characteristics include: fever, cough, sore throat, fatigue, headache, myalgia, anosmia, loss of taste, and dyspnea, which makes it difficult to differentiate from other respiratory infections. In some patients, at the end of the first week, the disease may progress to respiratory pneumonia, respiratory failure, and death. This progression is associated with a huge increase in the inflammatory cytokines, including IL2, IL7, IL10, GCSF, IP10, MCP1, MIP1A and TNFa. The mean time from the onset of symptoms until de development of dyspnea is approximately 5 days and the onset of the acute respiratory distress syndrome (ARDS) is 
8 days. According to the series published, admission to the ICU is estimated to be around $25-30 \%$ of the patients affected; these percentages are reported in the large studies conducted mostly in China and the European countries, which are countries with the largest number of cases up to this moment. The most frequently reported complications are acute lung injury, ARDS, shock, acute renal injury and death. The patients that have recovered have achieved recovery after two to three weeks. The average hospital stay of patients who recovered was approximately 10 days. It has been found that in accordance with the behavior of the virus in other places around the world, adverse outcomes and death are more frequent among the elderly and in patients with underlying comorbidities. In general, the mortality rate is estimated to range between 2 and $3 \%$ of the total number of infected individuals. $(6,11,15-18)$

\section{DIAGNOSTIC TESTS}

It is important to clarify a few concepts to determine the usefulness of doing standardized diagnostic tests in all patients undergoing a diagnostic and/or therapeutic procedure under sedation, outside the operating room, as a criterion to decide whether to conduct the procedure or not.

Such tests may be considered a key component during the mitigation phase for the re-opening process, with a massive implementation of those tests to detect the virus: serologic and virologic testing; the former detect SARS-CoV-2 specific immunoglobulins (IgM and $\lg \mathrm{C}$ ) and provide estimates of the population exposure. This helps to understand the use of the basic reproductive number or Ro (which estimates the rate at which a disease may spread in a particular population)(19); the Ro number for this disease is 2 to 3 , and consistently, the forecasts estimate that the benefits of herd immunity (when a large proportion of the community becomes immune to the disease), will materialize when $50 \%$ to $66 \%$ of the population have been infected, whether symptomatic or not. These calculations may help to define the necessary level of surveillance and intervention. $(20,21)$.

The latter, virologic test or the real time reverse transcription polymerase chain reaction test ( $r R T-P C R)$ identifies the active disease. This type of test which is based on the detection of unique sequences of the RNA virus through NAAT (Nucleic Acid Amplification Test), is important to stop the transmission by identifying the patient and be able to do active intervention. The tests must be immediately accessible to everyone, with any symptom suggestive of the disease. Since asymptomatic is important, tests should be conducted in particular individuals with significant exposure, such as professors, industrial workers and healthcare providers, inter alia. (20-22)

Each test has a sensitivity and specificity in accordance with different variables so that the result is reliable and accurate. The positivity of the test is based on the following characteristics:

\section{RT-PCR}

- Site from which the sample is taken: samples taken from the upper respiratory tract detect a smaller number of viral particles as compared to samples taken from the lower respiratory tract. $(21,23)$

- Time at which the sample is collected: the highest detection of viral particles occurs on day 5 after the onset of symptoms, and progressively decreases after day 10. $(21,24)$.

- Severity of the clinical presentation: severe presentations have more viral excretion than the mild cases.

\section{Serological tests (IgC and IgM)}

The positivity of these tests depends on the timing of sampling after the onset of symptoms, and in the case of asymptomatic patients, after contact with confirmed and suspicious individuals. Different studies show that tests are positive after day 7, the percentage of positivity increases after day 10 , and is $100 \%$ positive on day 14 of the infection. $(21,25)$

This is evidence of the fact that the test outcomes depend on specific requirements for reliable results, particularly when dealing with asymptomatic patients. The Second Edition of the "Colombian Consensus on care, diagnosis, and management of the SARS-CoV-2/COVID-19 infection", particularly highlights the following recommendations:

Refrain from conducting diagnostic tests prior to surgical procedures due to their low diagnostic power to detect SARS CoV-2 infection in asymptomatic patients.(21)

And additionally, the Consensus gives a strong recommendation in favor of:

Using a pre-surgery questionnaire for screening probable SARS-CoV-2/ COVID-19 infection before surgery. (21)

These expert recommendations and the contributions of the world literature until now, lead to the conclusion that in case of sedation procedures outside the operating room, patients undergoing a procedure should not be subject to standardized serological or virologic tests. Moreover, in accordance with the discussion hereunder, it should be kept in mind that at this stage of the pandemic, every one of us is considered a potential transmitter; therefore, proper use of PPE and the administration of an adequate survey to check epidemiological links and the risk of the patient being a carrier of the virus, are the most valuable tools available in order to conduct the procedures according to safety standards for the patient, the specialist, and the team in charge of sedation. 


\section{PROCEDURES ASSOCIATED WITH THE PRODUCTION OF AEROSOLS}

To better understand the role of aerosols in the transmission of the virus, it is important to recall how are particles classified based on their size: thick particles are 2.5 to $10 \mathrm{mi}-$ crons, fine particle are less than 2.5 microns and ultrafine particles are 0.1 micron. The nose can typically filter air particles above 10 microns; if the particle is less than $10 \mathrm{mi}-$ crons, it can enter the respiratory tract, and if it is less than 2.5 microns it may reach the alveoli. It is currently believed that most of the transmission through respiratory secretions occurs in the form of large drops instead of small aerosols. Drops are usually heavy enough to be unable to travel long distances, and due to gravity, the larger drops quickly hit the floor; therefore, the transmission of COVID-19 via drops requires a very close physical proximity between an infected person and a susceptible individual. $(9,14,25)$

The problem arises when the viral particles are aerosolized through coughing, sneezing, or when aerosol-generating procedures are conducted, as described hereunder. In these cases, the particles may travel longer distances, with estimates of up to 20 feet (6 meters).(9) These clusters of aerosol drops may remain airborne in an area, even after the individual producing them has left the room, and this way facilitates contact with the people in the same room, and contaminate the nearby surfaces - furniture, equipment, stationary, door locks, etc.

It has been shown that the procedures associated with a larger production of aerosols in clinical care (nuclei of small particles that may penetrate standard surgical masks and contaminate a radius of scatter broader than the standard), are the following (26-31):

\footnotetext{
- Manual ventilation with facemask

- Tracheal intubation

- Non-invasive mechanical ventilation

- Tracheostomy
}

- Cricothyroidotomy

- Fibrobronchoscopy

- Airway suction

- Extubation

- Resuscitation thoracotomy

- Suture of blowing penetrating wounds (chest, neck)

- Necropsies

- Respiratory therapy

- High-frequency oscillatory ventilation

- Prone decubitus ventilation (PDV) .

- Nebulizer therapy

- Dental procedures

- Chest compressions during CPR

- Gl endoscopy and colonoscopy

- Removal of the gastrostomy tube

- Nasogastric tube insertion

- Transesophageal echocardiogram

- Labor and delivery care

It should be acknowledged that medical and dental procedures under sedation, outside the operating room, may be highly aerosol-generating, in accordance with the intervention approach: oral — such as dental or endoscopic procedures - , or the patient's spontaneous ventilation, when intervening other anatomical areas of the body - for instance, fertility procedures (follicle aspiration, hysteroscopies, etc.) since the patient may spontaneously cough or sneeze and aerosolize particles.

\section{PROCEDURE REFERRAL ACCORDING TO PATIENT}

Most medical and dental procedures conducted outside the operating room under sedation are considered elective; it is important to classify the population in times of the COVID-19 pandemic, in accordance with the survey administered to the patient at the time of scheduling the procedure, in order to identify whether the procedure may or may not be conducted and the level of risk of exposure for the healthcare team (Complementary content 1 and figure 1 ).

Keeping in mind the new scenario to which we are exposed with COVID-19, where all of us are considered potential carriers, one of the most important factors is the use of the PPE for the healthcare staff conducting the procedure, the patient and the person accompanying the patient after the sedation. This is illustrated in Table 1 , according to each particular case, including the administrative staff and housekeeping for each office.

\section{RECOMMENDATIONS FOR MEDICAL AND DENTAL PROCEDURES UNDER SEDATION, OUTSIDE THE OPERATING ROOM DURING THE COVID-19 PANDEMIC}

A number of concepts, definitions and guidelines have been reviewed in order to fulfill the goal of this article which is to issue recommendations for prevention and to protect healthcare workers and patients (26,27,32):

\section{Hand hygiene (5 moments) - Intensification of the WHO strategy
a. Before touching the patient
b. Before clean/aseptic procedures
c. After body fluid exposure/risk
d. After touching a patient
e. After touching patient surroundings

2. Adequate use of PPE

3. Administrative controls

4. Environmental and engineering controls

\section{General recommendations}

Following is a list of the general recommendations (13,33-35):

- Pursuant to the progressive reactivation of outpatient procedures, adequate patient selection is recommended, prioritizing those considered to be urgent and those authorized to reinitiate their activities in accordance with the guidelines of the government authorities. 
- In accordance with the review of the bibliography currently available and the recommendations of the The Second Edition of the "Colombian Consensus on care, diagnosis, and management of the SARS-CoV-2/COVID-19 infection", diagnostic tests shall not be conducted prior to surgical procedures, and in this case prior to medical and/or dental procedures under sedation outside the operating room, due to their poor ability to diagnose SARS CoV-2 infection in asymptomatic patients; however, a comprehensive assessment should be made to determine a potential epidemiological link, as shown on Table 2, in order to decide whether to conduct the procedure or not. If the procedure is considered to be urgent or high priority, but the patient presents symptoms on the day of the procedure, the procedure should be adjourned and the patient's health insurance provider shall be informed to continue with the appropriate management according to the protocols established by the Ministry of Health and Social Protection. Every patient should be considered suspicious for COVID-19 and all biosecurity measures should be followed in order to reduce the transmission of the disease among those involved with the procedures.

- The patient must know, understand and sign the informed consent to conduct the procedure under sedation and should additionally sign a consent to receive care during the COVID-19 pandemic, which includes questions about close contact with suspicious or confirmed patients, about the presence or absence of symptoms, hospital admissions during the pandemic, use of PPE required from the community, and compliance with the quarantine, as well as any other questions considered under the institutional protocols (Table 2).

- Following are the recommendations for the healthcare staff:

- Wear OR uniform to conduct the procedures instead or the regular street clothes.
- Remove any accessories (ear rings, rings, bracelets, etc.), mobile phones, computers, speakers, since they are all potential fomites.

- Shave your beard for proper seal of the N95 respirator

- Pull up your hair before placing the cap to prevent hair exposure during the procedure.

- Use easy-to-clean shoes, ideally shoes only used at work.

- The staff taking care of the patient scheduled for a procedure outside the operating room is required to use PPE according to the institutional protocol; the suggestion is to go over the recommendations of the Guidelines for the prevention, control and reporting of occupational accidents due to exposure to SARS CoV-2 (COVID-19) in healthcare institutions, issued by the Ministry of Health and Social Protection in March of this year (Table 2).

- Any asymptomatic patients shall use at least one surgical mask on every visit to the institution, wash their hands, and use alcohol gel; their body temperature must be checked using a non-contact thermometer. - Only one accompanying person is allowed, who should be asymptomatic, of age but under 65 years old, and should wear a surgical mask, complete hand hygiene when arriving at the doctor's office, and have negatively answered the questions in the COVID-19 survey.

- Patients should be scheduled with enough time in between to allow for social distancing and the implementation of cleaning, disinfection and sterilization protocols between each patient. The waiting rooms should not have any magazines, newspapers, or goods that may be passed from one person to another.

- The number of healthcare providers participating in the procedure shall be the minimum required and trainees should not be present to avoid additional exposure and a larger number of people in the procedure area.
- It is recommended to do a telemedicine pre-anesthesia evaluation to avoid unnecessary travel to the patient, with emphasis on the airway and medical history, clearly explaining the recommendations before the procedure and the informed consent that will be signed on the same day of the procedure.

- With regards to the procedure areas and mobile or fixed equipment $(26,36,37)$ :

- Cleaning the area with water and soap and disinfection with the usual agents (hypochlorite or organic chlorine at a concentration of $1000 \mathrm{ppm}$ or $70 \%$ alcohol) are recommended

- It is advisable to increase the frequency of routine hygiene procedures, particularly in the surfaces close to the patient and high contact, in addition to adhering to the institutional protocols.

- In the case of mobile units (endoscopy equipment, monitors) or fixed equipment (dental equipment, stretchers, desks, oxygen tanks, inter alia), emphasis should be placed on the disinfection of surfaces that are constantly touched by patients. One option to do this is the use of cleaner-disinfectant towels or disposable towels soaked in quaternary ammonia-type disinfectants.

- The evidence recommends that the procedure areas shall ideally be negative pressure rooms with a minimum of 6 air changes per hour; if this is not possible, the recommendation is to have a properly ventilated room that does not generate positive pressure to avoid contamination of the surrounding areas. (32)

\section{Specific recommendations for medical and dental procedures under sedation outside the operating room}

- Remove any unnecessary materials from the procedures area. 
TABLE 1. Personal protection equipment.

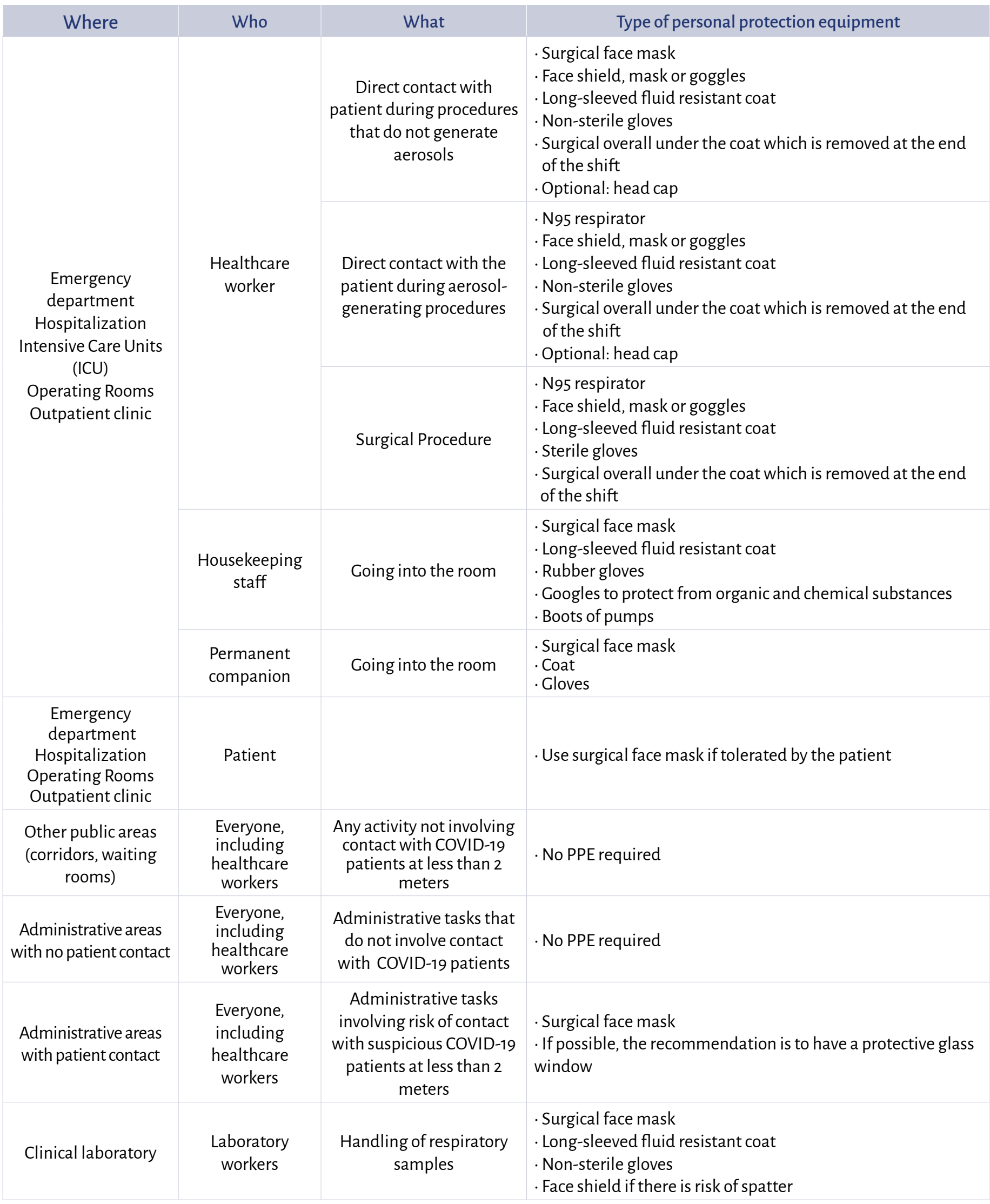


TABLE 2. Survey administered during the COVID-19 pandemic.

1. Have you traveled outside the city in the past 14 days?

2. Have you experienced any respiratory symptoms in the past 14 days? Fever, dry cough, shortness of breath, sore throat.

3. Have you experienced any loss of taste or smell in the past 14 days?

4. Have you been in close contact with people suspicious or positive for COVID-19?

5. Have you been in contact with people with respiratory symptoms in the past 14 days?

6. Have you been to the emergency department or hospitalized in the past 14 days?

7. Are you a healthcare worker or do you work for a healthcare institution?

8. If your answer to question 5 is yes, do you see any suspicious or COVID-19 positive patients?

9. Have you recently attended any large gatherings (>50 people)?

\begin{tabular}{ll} 
Yes__ & No \\
\hline Yes___ & No \\
Yes__ & No \\
\hline Yes___ & No \\
\hline Yes__ & No \\
\hline Yes__ & No \\
\hline Yes__ & No \\
\hline Yes__ & No \\
\hline Yes__ & No
\end{tabular}

SOURCE: Author.

FICURE 1. Scenarios and referral of patients for medical and dental procedures during the COVID-19 pandemic
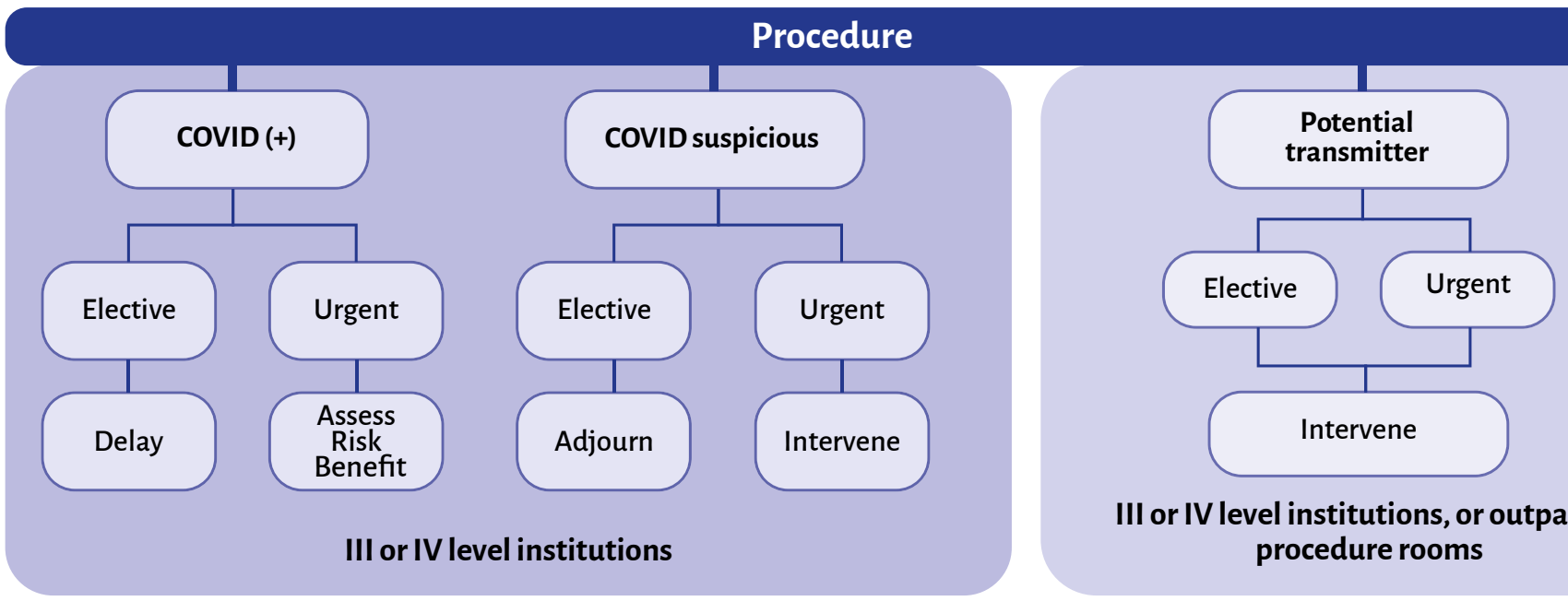

III or IV level institutions, or outpatient procedure rooms

SOURCE: Author.

- Check the patient's body temperature when admitting the patient into the office, using a non-contact thermometer and enter the information in the medical record.

- Keep the medical resuscitation and pharmacological equipment, as well as any advanced airway management units available, keeping in mind the complications inherent to the procedure, in accordance with the guidelines so far developed, which should not change despite the current pandemic.

- Cover up all monitors and infusion pumps with plastic covers or vinyl paper to allow for use avoiding touching the surface directly.

- Have the oxygen source available in the room or an oxygen tank properly covered.

- Anesthesia drugs and supplies to be used, should be prepared prior to admitting the patient to the procedure area.

- Complete the checklist before starting the procedure, including confirmation of the adequate PPE for the healthcare staff and the patient.

- Make sure that isopropyl alcohol gel is available.
- Every healthcare team member in contact with the patient must wear complete PPE.

- Use the minimum number of staff possible.

- Follow the double-gloving technique for airway access in case there is a need for it.

- The room temperature should comply with the universal standards $\left(18-22^{\circ} \mathrm{C}\right)$, to ensure comfort for the healthcare staff.

- Dispose of any drugs and supplies used with the patent.

- Keep the doors closed during the procedure. 
- Previously appoint one person in charge of delivering materials or medicines from the outside.

\section{Induction of sedation}

- Check for availability and operation of the equipment needed.

- Check monitoring, patent venous access, medication.

- Use rapid onset and clearance drugs such propofol, to shorten the recovery times and facilitate rapid patient discharge.

-Ensure that the patient has surgical face mask over the oxygen delivery equipment.

- Use low flows through the oxygen cannula - between 2-3 L/min, avoid using face mask, but in case of desaturation and need for manual ventilation, ensure the mask tight seal, deliver low volumes and continue using the nasal cannula after recovering spontaneous breathing.

- Perform slow, progressive and titrated inductions to avoid Grade IV sedation (general anesthesia) and apnea that require assisted ventilation.

- Capnography is recommended for followup during sedation and early decisionmaking in case of apnea and desaturation, in order to avoid invasive airway intervention. Eliminate the water trap after completing the procedure with the patient and ensure safe disposal.

- In case orotracheal intubation is required, consider the recommendations for managing the airway under general anesthesia for COVID-19.

-When using opioids such as fentanyl, the drug must be administered slowly to reduce the chances of drug-induced coughing.

\section{During the procedure}

- Make sure that the sedation objectives are maintained throughout the procedure to prevent the patient from exiting the desired plane of sedation, from moving and avoid any potential release or aerosols.

- Implement strategies for adequate postprocedure pain, and for the management of nausea and vomiting to prevent the release of aerosols during the process of recovery.

\section{Recovery and discharge}

- Minimize the chances of coughing during this phase.

- Recover the patient in the procedure area.

- Make sure that all the airway supplies, tubes, or disposables devices are duly packaged for safe disposal.

- Give the person accompanying the patient the written recommendations about alarm signs after sedation and answer any questions they may have.

- Inform the patient that a symptoms control telephone call will be scheduled 7 and 14 days after the procedure for epidemiological follow-up.

At the end of the procedure, the healthcare staff is required to comply with the recommendations to remove the $P E E$ to avoid any exposure resulting from poor PPE handling. $(26,31,38)$ :

- Remove the PPE items always in front of a peer - mirror modality -. Ensure the availability of containers for contaminated waste in the procedure room or in the office, so that all PPE items may be safely disposed. It is important to keep in mind the availability of containers for reusable items.

- Immediately remove the second pair of gloves and disinfect hands using rubbing isopropyl alcohol gel before getting undressed.

- Remove the fluid resistant disposable coat leaning forward, without contaminating your hands, remove the coat pulling from the neck and roll it without touching the front part of the coat. Then release the strap from the back and roll forward.

- Use isopropyl alcohol for hand hygiene without removing the gloves.

- Remove the face protection equipment starting with the face shield and place it on the appropriate area for disinfection.

- Use isopropyl alcohol for hand hygiene without removing the gloves.

- Then remove the goggles and wash them with water and soap.

- Use isopropyl alcohol for hand hygiene without removing the gloves.

- To remove the $\mathrm{N} 95$ respirator, hold the lower elastic straps and then the upper straps, remove them without touching the forehead and discard safely, according to the institutional protocol.

- Use isopropyl alcohol for hand hygiene without removing the gloves.

- Remove the head cap and discard safely.

- Use isopropyl alcohol for hand hygiene without removing the gloves.

- Remove the shoe covers and discard safely.

- Carefully remove gloves following the adequate technique and discard safely.

-Wash hands with water and soap pursuant to $\mathrm{WHO}$ recommendations.

It is important to highlight that each institution shall develop its own management protocols together with its team, and make sure that everyone is aware of them. Moreover, they should educate and instruct on the proper use of EPP according to the recommendations of the government agencies and the scientific organizations to prevent contagion due to poor doffing practices.

If all of us ensure compliance with the recommendations for managing medical and dental patients during this pandemic, we will accomplish our goal of delivering safe and quality care to our patients. 


\section{ETHICAL RESPONSIBILITIES}

\section{Protection of humans and animals}

The authors declare that no experiments in humans or animals were conducted in the course of this research project.

\section{Confidentiality of the information}

The authors declare that they followed the protocols applicable in their institution regarding the publication of patient information.

\section{Right to privacy and informed consent}

The authors declare that no patient data have been disclosed in this article.

\section{ACKNOWLEDGEMENT}

\section{Contributions}

LSA: Design of the original project, planning of the article, collection of data, drafting and final approval of the manuscript.

\section{Aid to conduct the study}

None

\section{Final contribution and sponsorship}

None

\section{Conflict of interests}

The author has no conflict of interest to disclose.

\section{ACKNOWLEDGEMENT}

I thank my family for their unconditional support over the years I have been focused on the practice of my profession, particularly in the area of sedation, always committed to ensure the safety of the patient.

\section{REFERENCES}

1. World Health Organization (WHO). Director-General's opening remarks at the media briefing on COVID-19, 11 de marzo del 2020. Available at: https://www.who.int/dg/speeches/detail/who-director-general-s-openingremarks-at-the-media-briefing-on-covid-19--11-march-2020.

2. Wang C, Horby PW, Hayden FG, Gao GF. A novel coronavirus outbreak of global health concern. Lancet. 2020;395(10223):470-3. doi: https://doi. org/10.1016/S0140-6736(20)30185-9.

3. Hui DS, Azhar E, Madani T, et al. The continuing 2019-nCoV epidemic threat of novel coronaviruses to global health. The latest 2019 novel coronavirus outbreak in Wuhan, China. Int ] Infect Dis. 2020;91:264-6. doi: https://doi.org/10.1016/j. ijid.2020.01.009

4. Xinhua. China's CDC detects a large number of new coronaviruses in the South China seafood market in Wuhan [internet]. 2020. Available at: https://www.xinhuanet.com/202001/27/c_1125504355.htm.

5. World Health Organization (WHO). Coronavirus disease (COVID-19) outbreak: rights, roles and responsibilities of health workers, including key considerations for occupational safety and health: interim guidance [internet]. 19 de marzo de 2020. Available at: https://apps. who.int/iris/handle/10665/331510.

6. Chen N, Zhou M, Dong X, et al. Epidemiological and clinical characteristics of 99 cases of 2019 novel coronavirus pneumonia in Wuhan, China: a descriptive study. Lancet. 2020;395:507-13. doi :https://doi.org/10.1016/S0140-6736(20)30211-7

7. Xian $P$, Xin $X$, Yuqing $L$, et al. Transmission routes of $2019 \mathrm{nCoV}$ and controls in dental practice. Int] Oral Sci. 2020;12:9. doi: https://doi.org/10.1038/s41368-020-0075-9

8. Argentina.gob.ar. Identificación y seguimiento de contactos. [internet]. S. f. Available at: https://www.argentina.gob.ar/salud/coronavirus-COVID-19/Identificacion-y-seguimiento-de-contactos.

9. Scott F, Michelle S. COVID-19 and the problem with dental aerosols Dentistry is classified in the very-high-risk category of occupations involved with aerosol production. What does this have to do with COVID-19? Quite a lot. Here is the latest Research [internet]. 7 de abril de 2020. Available at: https://www.perioimplantadvisory.com/periodontics/oral-medicine-anesthetics-and-oral-systemic-connection/ article/14173521/covid19-and-the-problem-with-dental-aerosols.

10. Tran K, Cimon K, Severn M, Pessoa-Silva CL, Conly ]. Aerosol generating procedures and risk of transmission of acute respiratory infections to healthcare workers: a systematic review. PLoS One. 2012;7(4):e35797-e.

11. Singhal T. A review of coronavirus disease-2019 (COVID-19). Indian J Pediatr. 2020;87(4):281-6. doi: https://doi.org/10.1007/s12098-020-03263-6

12. Young BE, Ong SWX, Kalimuddin S, et al. Epidemiologic features and clinical course of patients infected with SARS-COV-2 in Singapore. JAMA. 2020;323(15):1488-1494. doi: 10.1001/ jama.2020.3204.

13. Wujtewicz M, Dylczyk-Sommer A, Aszkiełowicz A, et al. COVID-19 - what should anaethesiologists and intensivists know about it? Anaesthesiol Intensive Ther. 2020;52(1):3441. doi: https://doi.org/10.5114/ait.2020.93756.

14. Van Doremalen N, Bushmaker T, Morris DH, et al. Aerosol and surface stability of SARSCoV- 2 as compared with SARS-CoV-1. N Engl ] Med. 2020 [Ahead of print]. doi: 10.1056/NEJMc2004973.

15. Kakodkar P, Kaka N, Baig M. A comprehensive literature review on the clinical presentation, and management of the pandemic coronavirus disease 2019 (COVID-19). Cureus. 2020;12(4):e7560. doi 10.7759/cureus.7560.

16. Coronavirus Outbreak [internet]. 23 de febrero de 2020. Available at: https://www.worldometers.info/coronavirus/

17. Huang C, Wang Y, LiX, et al. Clinical features of patients infected with 2019 novel coronavirus in $\mathrm{Wu}$ han, China. Lancet. 2020;395(10223):947-506. doi: https://doi.org/10.1016/S0140-6736(20)30183-5.

18. Conzález A, Escudero P, Peñasco Y, etal. Cuidados intensivos durante la epidemia coronavirus 2019. Medicina Intensiva. 2020;44(6):35162. doi: $10.1016 / j$.medin.2020.03.001.

19. Ridenhour B, Kowalik J, Shay D. El número reproductivo básico (Ro): consideraciones para su aplicación en la salud pública. Rev Panam Salud Publica. 2015;38(2):167-76.

20. Walensky RP, Del Río C. From mitigation to containment of the COVID-19 pandemic: Putting the 
SARS-CoV-2 genie back in the bottle. JAMA. 2020 [Ahead of print]. doi:10.1001/jama.2020.6572

21. Saavedra Trujillo CH. Consenso colombiano de atención, diagnóstico y manejo de la infección por SARS-COV-2/COVID-19 en establecimiento de atención de la salud. Recomendaciones basadas en consenso de expertos e informadas en la evidencia. Infectio. 2020;24(3,S2);1-120. doi: http://dx.doi.org/10.22354/in.v24i3.894

22. World Health Organization (WHO). Laboratory testing for coronavirus disease 2019 (COVID-19) in suspected human cases: interim guidance [internet]. 2 de marzo de 2020 . Available at: https://apps.who.int/iris/handle/10665/331329.

23. Chang D, Mo G, Yuan X, Tao Y, PengX, Wang F-S, et al. Time kinetics of viral clearance and resolution of symptoms in novel coronavirus infection. Am] Respirat Crit Care Med. 2020;201:1150-2. doi: https:// doi.org/10.1164/rccm.202003-0524LE

24. Li Z, Yi Y, Luo X, Xiong N, Liu Y, Li S, et al. Development and clinical application of a rapid IgM-lgC combined antibody test for SARS-CoV-2 infection diagnosis. ] Med Virol. 2020. 2020;92:1518-24. doi: https://doi.org/10.1002/jmv.25727

25. Guo L, Ren L, Yang S, Xiao M, Chang, Yang F, et al. Profiling early humoral response to diagnose novel coronavirus disease (COVID-19). Clin Infect Dis. 2020/03/22. 2020. 2020;71(15):778-85. doi: https://doi.org/10.1093/cid/ciaa310

26. Calabrese G. Actualización de los riesgos biológicos para anestesiólogos en la atención de pacientes afectados por SARS-CoV-2, COVID-19. Colombian Journal of Anesthesiology. 2020;48(3):138-44. doi: https://doi.org/10.1097/Cl9.0000000000000173

27. Trujillo CHS. Consenso colombiano de atención, diagnósticoymanejo delainfección porSARS-COV-2/ COVID-19 en establecimiento de atención de la salud. Recomendaciones basadas en consenso de expertos e informadas en la evidencia. Infectio. 2020; 24 (3): 1-102. doi: http://dx.doi.org/10.22354/in.v24i3.891

28. Meselson M. Droplets and aerosols in the transmission of SARS-CoV-2. N Engl JMed. 2020;382:2063. doi: 10.1056/NEJMc2009324.
29. Gan WH, Wah ], Koh D. Preventing intra-hospital infection and transmission of coronavirus disease 2019 in healthcare workers, safety and health at work. 2020;11(2):241-3. doi: https://doi.org/10.1016/j.shaw.2020.03.001.

30. Organización Panamericana de la Salud (OPS). Pasos para quitarse el equipo de protección personal (EPP), incluido el overol [internet]. S.f. Available at: https://www.paho. org/hq/dmdocuments/2015/Equipo-de-proteccion-personal-2015-4-A3-ESP.pdf.

31. Covernment of Canada. Infection prevention and control for novel coronavirus (2019$\mathrm{nCoV}$ ): interim guidance for acute healthcare settings [internet]. 2020. Available at: https:// www.canada.ca/en/public-health/services/ diseases/2019-novel-coronavirus-infection/ health-professionals/infection-prevention-control-covid-19-second-interim-guidance.html

32. Kah Ti L, Ang LS, Foong TW, Wei Ng BS. What we do when a COVID-19 patient needs an operation: operating room preparation and guidance. Can ] Anesth 2020;67:756-8. doi: https://doi.org/10.1007/s12630-020-01617-4

33. Sociedad Española de Anestesiología y Reanimación (SEDAR). Manejo de la vía Aérea en paciente con COVID-19 [internet]. Available at: https://anestesiar.org/WP/uploads/2020/03/ Manejo-v\%C3\%ADa-a\%C3\%Agrea-paciente-con-coronavirus-SEDAR.pdf

34. Asociación Colombiana de Medicina Crítica y Cuidado Intensivo (AMCl). Declaración de consenso en medicina critica para la atención multidisciplinaria del paciente con sospecha o confirmación diagnóstica de COVID-19 [internet]. 30 de marzo de 2020. Available at: https://www.amci.org.co/consenso-covid19

35. Wax RS, Christian MD. Practical recommendations for critical care and anesthesiology teams caring for novel coronavirus (2019-nCoV) patients. Can J Anesth/J Can Anesth. 2020;67:568-76. doi: https://doi.org/10.1007/s12630-020-01591-X.

36. Dexter F, Parra M, Brown ], Loftus R. Perioperative COVID-19 defense: An evidence-based approach for optimization of infection control and operating room management. Anesthesia \& Analgesia ][Ahead of print]. doi: 10.1213/ ANE.0000000000004829.
37. CADTH. Aerosol-generating procedures and risk of transmission of acute respiratory infections: a systematic review. (CADTH Health technology assessment) [internet]. Ottawa (ON); 2013. Available at: https:// www.cadth.ca/aerosol-generating-procedures-and-risk-of-transmissionacute-respiratory-infections-systematic-review.

38. Ministerio de Salud y Protección Social. Lineamientos para Prevención, Control y Reporte de Accidente Laboral por Exposición Ocupacional al SARS CoV-2 (COVID-19) en Instituciones de Salud. Gestión de la protección social en salud. Bogotá; 2020.

39. Sociedad Colombiana de Anestesiología y Reanimación (S.C.A.R.E.). Recomendaciones para el personal de salud en el Contexto de fase de mitigación por SARS COV2 durante procedimientos quirúrgicos $y$ diagnósticos [internet]. 2020. Available at: https://www.comunidadacademicascare. com/394-recomendaciones-para-el-personal-de-salud-en-elcontexto-de-fase-de-mitigación-por-sars-cov-2durante-procedimientos-quirúrgicos-y-diagnósticos.html

40. Ministerio de Salud y Protección Social. Colombia entra en fase de mitigación de la COVID-19 [internet]. 31 de marzo de 2020. Available at: https://www.minsalud.gov.co/ Paginas/Colombia-entra-en-fase-de-mitigacion-de-la-COVID-19.aspx.

41. Ministerio de Salud y Protección Social. En La fase de mitigación lo que cambia para la ciudadanía es que tenemos circulación local del coronavirus: Carlos Álvarez [internet]. 1 de abril de 2020. Available at: https://www. minsalud.gov.co/Paginas/En-La-fase-de-mitigacion--lo-que-cambia-para-la-ciudadania-es--que-tenemos-circulacion-local-del-coronavirus-Carlos-Alvarez.aspx.

42. Ge Zyu, Yang L ming, Xia ] jia, Fu X hui, Zhang $Y$ zhen. Possible aerosol transmission of COVID-19 and special precautions in dentistry. ] Zhejiang University: Science B. 2020;21:361-8. doi: https://doi.org/10.1631/jzus.B2010010 
COMPLEMENTARY CONTENT 1. Classification of the population during the COVID-19 pandemic.

\begin{tabular}{|c|l|}
\hline \multicolumn{1}{|c|}{ Classification } & \multicolumn{1}{c}{ Criteria } \\
\hline SOVID-19 $(+)$ & Patient with or without symptoms, with confirmed rRT-PCR test \\
\hline Potential transmitter & $\begin{array}{l}\text { Any patient with a clinical presentation of acute respiratory infection } \\
\text { (ARI), regardless of its severity, without a confirmatory test }\end{array}$ \\
\hline & $\begin{array}{l}\text { At the onset of the mitigation phase, where there is local circulation of } \\
\text { the virus and in the absence of epidemiological link. This means that the } \\
\text { whole population is considered potential transmitters }\end{array}$ \\
\hline
\end{tabular}

SouRCE: Adapted by the author from MinSalud (40), MinSalud (41) and Ge (42). 